JPPUMA: Jurnal Ilmu Pemerintahan dan Sosial Politik UMA Uournal of Governance and Political

Social UMA), 7(2) (2019): 93-101, DOI: http://dx.doi.org/10.31289/ippuma.v7i2.2563

JPPUMA: Jurnal Ilmu Pemerintahan dan Sosial Politik UMA

(Journal of Governance and Political Social UMA)

Available online http://ojs.uma.ac.id/index.php/jppuma

\title{
Analisis Undang-Undang Nomor 7 Tahun 2017 tentang Pemilihan Umum
}

\section{Analysis of Law Number 7 of 2017 about General Elections}

\author{
Raja Ahmad Faisal Harahap* \& Khairul Fahmi \\ Konsentrasi Tata Kelola Pemilu, Program Magister Ilmu Politik, Fakultas Ilmu Sosial dan \\ Politik, Universitas Andalas, Indonesia
}

Diterima: 16 Mei 2019; Disetujui 04 September 2019; Dipublikasikan 01 Desember 2019

\begin{abstract}
Abstrak
Penelitian ini bertujuan untuk menganalisis Undang-Undang Nomor 7 tahun 2017 tentang Pemilihan Umum, yang berkaitan dengan pengelolaan tugas, kewajiban dan kewenangan petugas Kelompok Penyelenggara Pemungutan Suara pada Pemilu 2019. Selain itu menganalisis aspek kesehatan petugas Kelompok Penyelenggara Pemungutan Suara pada Pemilu 2019 karena pasca penyelenggaraan pemilu 2019 banyak petugas Petugas Kelompok Penyelenggara Pemungutan Suara yang meninggal dunia dan sakit disejumlah wilayah Indoensia. Metode penelitian ini menggunakan pendekatan kualitatif dengan melakukan studi literatur dari bermacam sumber yang relevan. Hasil penelitian ini menunjukkan bahwa perlunya pengelolaan tugas, kewajiban dan kewenangan petugas Kelompok Penyelenggara Pemungutan Suara secara proporsional baik pada tahapan pemungutan suara dan juga perhitungan suara. Selain itu perlunya memperhatikan aspek kesehatan petugas petugas Kelompok Penyelenggara Pemungutan Suara. Hal itu patut diduga disebabkan oleh sistem pemilu serentak yang rumit dan ketidaksiapan dari sisi pengelolaan penyelenggaran pemilu.

Kata Kunci: Analisis, Undang-Undang No 7 Tahun 2017, Pemilu 2019.
\end{abstract}

\section{Abstract}

This study aims to analyze Law Number 7 of 2017 concerning General Elections, relating to the management of the duties, obligations and authority of polling group administrators in 2019 elections. Besides analyzing the health aspects of polling group officers in 2019 elections due to post-implementation 2019 elections many officers of the Organizers of the Voting Group died and were sick in a number of Indonesian regions. This research method uses a qualitative approach by conducting literature studies from various relevant sources. The results of this study indicate that the need to manage the duties, obligations and authority of the Voters Organizing Group officers proportionally both at the stage of voting and also the vote count. In addition, it is necessary to pay attention to the health aspects of the polling group officers. That should be allegedly caused by a complicated simultaneous electoral system and unpreparedness in the management of election management.

Keywords: Analysis, Undang-Undang No 7 Tahun 2017, General Election 2019

How to Cite: Harahap, R.A.F. \& Fahmi, K (2019). Analisis Undang-Undang Nomor 7 Tahun 2017 tentang Pemilihan Umum. JPPUMA: Jurnal Ilmu Pemerintahan dan Sosial Politik UMA (Journal of Governance and Political Social UMA), 7(2): 93-101

*Corresponding author:

E-mail: kpu11indonesia@gmail.com
ISSN 2549-1660 (Print)

ISSN 2550-1305 (Online) 


\section{PENDAHULUAN}

Pemilu 2019 yang lalu menyisakan duka mendalam bagi publik karena ada sebanyak 469 petugas Kelompok Penyelenggara Pemungutan Suara (KPPS) wafat dan 4.602 orang sakit usai menyelenggarakan pemilu dan kemungkinan jumlah korban jiwa dapat bertambah mengingat masih terdapat petugas Kelompok Penyelenggara Pemungutan Suara (KPPS) sedang perawatan medis (detikNews, 10 Mei 2019). Menurut Ilham Syahputra selaku Anggota Komisi Pemilihan Umum (KPU) Divisi Teknis Penyelenggara, hal tersebut terjadi karena sistem pemilu serentak 2019 yang cukup rumit sehingga mengakibatkan kelelahan yang luar biasa pada penyelenggara pemilu di tingkat bawah, khususnya petugas Kelompok Penyelenggara Pemungutan Suara (KPPS) (Kompas, 23 April 2019.

Kerumitan pemilu serentak 2019, setidaknya terlihat dari penyelenggaraan pemilu di tingkat Tempat Pemungutan Suara (TPS). Petugas Kelompok Penyelenggara Pemungutan Suara (KPPS) harus menyelenggarakan pemungutan suara dan penghitungan suara untuk 2 pasangan calon presiden, 16 partai politik nasional, baik itu untuk Dewan Perwakilan Rakyat (DPR), Dewan Perwakilan Rakyat Daerah (DPRD) Provinsi, Dewan Perwakilan Rakyat Daerah (DPRD) Kabupaten/Kota, 4 partai politik lokal (Aceh), serta sejumlah calon Dewan Perwakilan Daerah (DPD), dengan waktu yang cukup singkat. Sesuai jadwal penyelenggaraan pemilu, penyaluran hak pilih di Tempat Pemungutan Suara (TPS) dijadwalkan dari pukul 07.00-13.00 waktu setempat. Setelah itu diteruskan untuk penghitungan suara sampai dengan jam 24.00, namun apabila perhitungan belum berakhir maka dapat diteruskan hingga jam 12.00 keesokan harinya yaitu tanggal 18 April 2019. (Liputan6, 16 April 2019).

Dengan jadwal dan waktu yang telah ditentukan tersebut, petugas Kelompok
Penyelenggara Pemungutan Suara (KPPS) dituntut harus bekerja ekstra keras dan hati-hati dalam melakukan penghitungan suara karena formulir-formulir yang harus diisi di tingkat Tempat Pemungutan Suara (TPS) tergolong kompleks dan rumit.

Keinginan banyak pihak untuk dilakukan evaluasi Pemilu serentak tentulah patut dipertimbangkan karena rumitnya penyelenggaraan pemilu serentak yang lalu. Pemilu seyogianya diselenggarakan dengan sistem pemilu yang sederhana. Surbakti (Soliha, 2018) karena pemilu menjadi sarana terbaik untuk memfasilitasi pergantian kekuasaan yang damai (Rahmatunnisa, 2017). Sehingga kesuksesan penyelenggaraan pemilu adalah tolak ukur sistem demokrasi dari suatu negara karena partisipasi rakyat dalam menyalurkan hak pilihnya dalam pergantian pemerintahan di suatu negara (Triono, 2017).

Selanjutnya evaluasi terhadap Pemilihan serentak 2019 membutuhkan kajian yang spesifik dan komperhensif dari seluruh stake holder pemilu, baik itu evaluasi dari aspek regulasi pemilu dan pengelolaan penyelenggaraan pemilu. Sehingga, berdasarkan uraian tersebut, fokus masalah yang akan ditelaah pada penelitian ini adalah bagaimanakah penyelenggaraan Pemilu 2019 di tingkat Kelompok Penyelenggara Pemungutan Suara (KPPS) sehingga menimbulkan banyak korban meninggal dunia dan sakit. Hal ini menyangkut bagaimana pengelolaan Kelompok Penyelenggara Pemungutan Suara (KPPS) pada Pemilu 2019, baik dari pelaksanaan tugas, kewajiban, kewenangan dan aspek kesehatan petugas Kelompok Penyelenggara Pemungutan Suara (KPPS).

Penelitian ini bertujuan untuk menganalisis Undang-Undang Nomor 7 tahun 2017 tentang Pemilihan Umum, yang berkaitan dengan pengelolaan tugas, kewajiban dan kewenangannya petugas Kelompok Penyelenggara Pemungutan Suara (KPPS) pada Pemilu 2019. 
Kemudian menganalisis aspek kesehatan petugas Kelompok Penyelenggara Pemungutan Suara (KPPS) pada Pemilu 2019.

\section{METODE PENELITIAN}

Studi kepustakaan adalah metode penelitian yang diterapkan dalam penelitian ini, yakni dengan mengumpulkan, menelaah berbagai dokumen dan laporan yang berhubungan dengan topik tulisan ini. Dari studi kepustakaan tersebut, berbagai refrensi dan hasil penelitian sebelumnya dapat dipelajari sehingga berguna dalam memperoleh landasan teori tentang masalah yang akan diteliti (Sarwono, 2016)

Tahapan awal penelitian ini adalah dengan melakukan pemilihan topik seputar fenomena yang menjadi perhatian banyak pihak. Selanjutnya mencari informasi dan data yang bersumber dari buku, jurnal, internet tentang topik yang bersangkutan. Kemudian, melakukan analisis terhadap informasi dan data tersebut, serta mengkonstruksi dan menyajikannya kedalam bentuk tulisan ilmiah.

\section{HASIL DAN PEMBAHASAN}

Analisis Undang-Undang Nomor 7 tahun 2017 tentang Pemilihan Umum,

Berdasarkan Pasal 6 UU No 7 Tahun 2017, Komisi Pemilihan Umum terdiri atas KPU Pusat, KPU Provinsi, KPU Kabupaten/Kota, Panitia Pemilihan Kecamatan, Panitia Pemungutan Suara, Panitia Pemilihan Luar Negeri, Kelompok Penyelenggara Pemungutan Suara dan Kelompok Penyelenggara Pemungutan Suara Luar Negeri.

Dari hirarki penyelenggara pemilu tersebut terlihat bahwa Kelompok Penyelenggara Pemungutan Suara (KPPS) merupakan ujung tombak dari pelaksanaan pemilu di Indonesia. Sebagai ujung tombak kerap dihadapkan pada pekerjaan yang cukup berat yang dapat menimbulkan tekanan mental dan kelelahan fisik. Hal tersebut bisa terlihat dari besarnya jumlah petugas KPPS yang sakit dan kehilangan nyawa dalam menjalankan tugas. Terakhir tercatat ada 469 orang yang kehilangan nyawa dan 4.602 orang sakit pasca pemilu 2019. Selain itu ditemukan juga kasus lainnya seperti korban tabrakan, keguguran dan bunuh diri (Republika, 23 April 2019)

Peristiwa meninggalnya petugas Kelompok Penyelenggara Pemungutan Suara (KPPS) pada sejumlah wilayah di Indonesia, penting menjadi bahan evaluasi bagi KPU untuk membenahi dan memperbaiki pengelolaan penyelenggaraan pemilunya, khususnya untuk pengelolaan tugas dan kewajiban serta kewenangan petugas Kelompok Penyelenggara Pemungutan Suara (KPPS).

Pengelolaan penyelenggaraan pemilu diperlukan untuk mengantisipasi beban tugas yang tidak merata di tingkat Kelompok Penyelenggara Pemungutan Suara (KPPS) sebagaimana yang terjadi pada Pemilu 2019. Clayton Reeser (Wijaya dan Rifai, 2016) mengemukakan bahwa pengelolaan atau manajemen itu penting dalam memanfaatkan sumber daya fisik dan manusia dengan cara yang terencana, koordinatif, terorganisir, terarah dan terawasi. Pengelolaan terhadap sumber daya manusia begitu kompleks bila dibandingkan dengan pengelolaan terhadap sumber daya mesin. Sumber daya manusia sifatnya unik, mempunyai perasaan yang tidak tampak dari luar secara jelas dan tidak mudah ditebak (Sanjaya, 2012)

Dengan demikian, Kelompok Penyelenggara Pemungutan Suara (KPPS) menjalankan tugas, kewajiban dan kewenangannya haruslah bertindak dengan terencana, terarah dan diawasi oleh atasannya yaitu Panitia Pemungutan Suara (PPS), Panitia Pemilihan Kecamatan (PPK) dan Komisi Pemilihan Umum Daerah (KPUD) Kabupaten/Kota. 
Selanjutnya pelaksanaan tugas dan beban kerja di tingkat Kelompok Penyelenggara Pemungutan Suara (KPPS) penting dikelola dengan baik kedepan untuk memastikan bahwa setiap petugas Kelompok Penyelenggara Pemungutan Suara (KPPS) mendapatkan beban kerja yang proporsional dan tidak berlebihan. Pembagian kerja, tanggungjawab kewenangan yang proporsional dan seimbang dapat mengurangi tingkat kelelehan yang tinggi dan tekanan psikologis yang dialami oleh petugas Kelompok Penyelenggara Pemungutan Suara (KPPS).

Kemudian, petugas Kelompok Penyelenggara Pemungutan Suara (KPPS) perlu diarahkan dan dibimbing dalam melakukan tugas dan kewajibannya sebagai penyelenggara pemilu, seperti diadakan bimbingan teknis dan atau simulasi pelaksanaan penyaluran hak suara dan perhitungan suara oleh Panitia Pemungutan Suara (PPS).

Setidaknya bimbingan teknis atau simulasi penyaluran hak suara dan perhitungan suara dilakukan paling sedikit sebanyak 2 kegiatan, dengan tahapan, yaitu: 1) bimbingan terkait tugas, kewajiban dan kewenangannya sebagai penyelenggara pemilu, 2) simulasi pelaksanaan penyaluran suara dan perhitungan suara di Tempat Pemungutan Suara (TPS), baik itu untuk pemilihan Presiden dan juga Legislatif. Kemudian menggelar diskusi untuk mengidentifikasi segala kemungkinan persoalan yang muncul di Tempat Pemungutan Suara (TPS) dan mencari solusinya. Dengan demikan seluruh petugas Kelompok Penyelenggara Pemungutan Suara (KPPS) telah terlatih untuk menjalankan tugasnya dan memiliki kesiapan pengetahuan dan mental dalam menghadapi permasalahan di Tempat Pemungutan Suara (TPS).

Berdasarkan Undang-Undang Nomor 7 tahun 2017 tentang Pemilihan Umum Pasal 60 menjelaskan, Kelompok Penyelenggara Pemungutan Suara (KPPS) memiliki sejumlah tugas, yaitu: a) mengumumkan daftar pemilih tetap di Tempat Pemungutan Suara (TPS); b) menyerahkan Daftar Pemilih Tetap (DPT) kepada saksi peserta pemilu yang hadir dan pengawas Tempat Pemungutan Suara (TPS) dan dalam hal peserta pemilu tidak memiliki saksi, Daftar Pemilih Tetap (DPT) diserahkan kepada peserta Pemilu; c) melaksanakan pemungutan dan penghitungan suara di Tempat Pemungutan Suara (TPS); d) membuat berita acara pemungutan dan penghitungan suara serta membuat sertifikat penghitungan suara dan wajib menyerahkannya kepada saksi peserta pemilu, pengawas Tempat Pemungutan Suara (TPS), dan Panitia Pemilihan Kecamatan (PPK) melalui Panitia Pemungutan Suara (PPS); e) melaksanakan tugas lain yang diberikan oleh Komisi Pemilihan Umum (KPU), Komisi Pemilihan Umum (KPU) Provinsi, Komisi Pemilihan Umum (KPU) Kabupaten/Kota dan Panitia Pemilihan Kecamatan (PPK) melalui Panitia Pemungutan Suara (PPS); f) menyampaikan surat undangan atau pemberitahuan kepada pemilih sesuai Daftar Pemilih Tetap (DPT) untuk menggunakan hak pilihnya di Tempat Pemungutan Suara (TPS); g) melaksanakan tugas lain sesuai dengan ketentuan peraturan perundangundangan.

Selanjutnya, berdasarkan Pasal 62 Undang-Undang Nomor 7 Tahun 2017, petugas KPPS memiliki kewajiban, yaitu: a) menempelkan DPT di TPS; b) menindaklajuti dengan segera temuan dan laporan yang disampaikan saksi, pengawas Tempat Pemungutan Suara (TPS), Panitia Pengawas Pemilu (Panwaslu) Kelurahan/Desa, Peserta Pemilu dan masyarakat pada hari pemungutan suara; c) menjaga dan mengamankan keutuhan kotak suara kepada Panitia Pemungutan Suara (PPS) dan Panitia Pengawas Pemilu (Panwaslu) Kelurahan/Desa; d) menyerahkan hasil penghitungan suara 
kepada Panitia Pemungutan Suara (PPS) dan Panitia Pengawas Pemilu (Panwaslu) Kelurahan/Desa menyerahkan kotak suara tersegel yang berisi surat suara dan; e) sertifikat hasil penghitungan suara kepada Panitia Pemilihan Kecamatan (PPK) melalui Panitia Pemungutan Suara (PPS) pada hari yang sama; f) melakukan kewajiban lain yang diberikan oleh Komisi Pemilihan Umum (KPU), Komisi Pemilihan Umum (KPU) Provinsi, Komisi Pemilihan Umum (KPU) Kabupaten/Kota, Panitia Pemilihan Kecamatan (PPK) dan Panitia Pemungutan Suara (PPS) sesuai dengan peraturan perundang-undangan; g) melaksanakan kewajiban lain sesuai dengan ketentuan peraturan perundangundangan.

Dari tugas dan kewajiban Kelompok Penyelenggara Pemungutan Suara (KPPS) diatas maka jelas terlihat bahwa petugas Kelompok Penyelenggara Pemungutan Suara (KPPS) tidak hanya bekerja untuk melakukan pemungutan dan penghitungan suara saja namun juga dibebankan sejumlah tugas lainnya seperti melaksanakan kewajiban lain yang diberikan oleh KPU, KPU Provinsi, KPU Kabupaten/Kota.

Kemudian, berdasarkan Pasal 28 Peraturan Komisi Pemilihan Umum (KPU) No 3 tahun 2019 tentang Pemungutan dan Penghitungan Suara Dalam Pemilihan Umum, bahwa tugas dan kewajiban Kelompok Penyelenggara Pemungutan Suara (KPPS) pada tahap pemungutan suara dibagi menjadi masing-masing 7 bagian yang terperinci, mulai dari Ketua KPPS hingga 6 anggota KPPS. Namun pembagian tugas dan tanggung jawab pada tahap penghitungan suara tidak diatur dalam Peraturan KPU tersebut sehingga pelaksanaan tugas Kelompok Penyelenggara Pemungutan Suara (KPPS) besar kemungkinan tidak proporsional sehingga pekerjaan dapat terbebani pada seseorang atau beberapa petugas Kelompok Penyelenggara Pemungutan Suara (KPPS) saja.
Padahal pelaksanaan penghitungan suara tergolong rumit. Kerumitan proses penghitungan suara terlihat dari petugas Kelompok Penyelenggara Pemungutan Suara (KPPS) yang harus mengitung perolehan suara untuk 2 pasangan calon presiden, 16 partai politik nasional, baik itu untuk Dewan Perwakilan Rakyat (DPR), Dewan Perwakilan Rakyat Daerah (DPRD) Provinsi, Dewan Perwakilan Rakyat (DPRD) Kabupaten/Kota, 4 partai politik lokal (khusus daerah Aceh), serta sejumlah calon Dewan Perwakilan Daerah (DPD) dengan waktu relatif singkat yaitu mulai pukul 13.00 sampai pukul 24.00 waktu setempat. Kemudian, apabila ternyata perhitungan suara belum rampung maka dapat dilanjutkan secara tidak terputus paling lama sampai dengan jam 12.00 keesokan harinya.

Selain itu petugas Kelompok Penyelenggara Pemungutan Suara (KPPS) juga diwajibkan menuangkan hasil perhitungan suara tersebut kedalam formulir-formulir dengan rangkap yang cukup banyak sesuai dengan jumlah peserta pemilihan, baik untuk para saksi Pilpres dan juga Pileg serta kemudian untuk pengawas pemilu lapangan. Belum lagi bila terjadi salah hitung oleh petugas KPPS, tentu hal tersebut menambah tekanan secara mental dan fisik karena penyelenggara pemilu kerap dibayangbayangi persoalan independensi, dari beberapa pelaksanaan pemilu sebelumnya (Riskiyono, 2013).

Kemudian juga perlu diatur tahapan pelaksanaan perhitungan suara, misalnya tahapan penghitungan dimulai dengan tahap: a) penghitungan suara pemilu presiden; b) penghitungan suara pemilu Dewan Perwakilan Rakyat (DPR); c) pengitungan suara pemilu Dewan Perwakilan Rakyat Daerah (DPRD) Provinsi; d) penghitungan suara pemilu Kabupaten/Kota; e) penghitungan suara pemilu Dewan Perwakilan Daerah (DPD).

Dengan demikian penghitungan suara dilakukan sesuai tahapan dan skala 
prioritas yang telah ditentukan. Selanjutnya, petugas Kelompok Penyelenggara Pemungutan Suara (KPPS) yang terdiri dari 7 orang tersebut dapat secara bergantian untuk melakukan proses tahapan penghitungan suara, sehingga seluruh petugas Kelompok Penyelenggara Pemungutan Suara (KPPS) memperoleh tugas dan kewajiban yang merata dan tidak terbebani pada petugas tertentu saja.

Selanjutnya, berdasarkan Pasal 18 huruf c UU No. 7 Tahun 2017, Komisi Pemilihan Umum (KPU) Kabupaten/Kota bertugas untuk mengoordinasikan dan mengendalikan tahapan penyelenggaraan pemilu di tingkat Kelompok Penyelenggara Pemungutan Suara (KPPS) dalam wilayah kerjanya.

Sehingga dengan peristiwa meninggalnya petugas Kelompok Penyelenggara Pemungutan Suara (KPPS) tersebut, Komisi Pemilihan Umum (KPU) Kabupaten/Kota kedepan perlu meningkatkan fungsi koordinasi dan pengendaliannya dengan cara melakukan kegiatan monitoring terhadap pelaksanaan tugas Kelompok Penyelenggara Pemungutan Suara (KPPS) diwilayah kerjanya, dengan melibatkan Panitia Pemilihan Kecamatan (PPK) dan Panitia Pemungutan Suara (PPS) di setiap wilayah kerja masing-masing.

Komisi Pemilihan Umum Daerah (KPUD), Panitia Pemilihan Kecamatan (PPK), Panitia Pemungutan Suara (PPS) secara bersama-sama melakukan monitoring dan pendampingan secara bergiliran dan bergantian di tiap-tiap TPS pada wilayah kerja masing-masing.

Dengan demikian, permasalahan yang muncul di tingkat Kelompok Penyelenggara Pemungutan Suara (KPPS) baik itu pada pelaksanaan penyaluran hak suara dan perhitungan suara dapat segera dikendalikan oleh petugas pada tingkatan lebih tinggi.

Monitoring tidak hanya untuk mengidentifikasi masalah yang terkait teknis penyelenggaraan pemilu namun juga dari sisi Sumber Daya Manusia (SDM) penyelenggaranya.

Sehingga bila ditemukan adanya keluhan seperti masalah kesehatan maka segera dapat di atasi oleh penyelenggara lainnya yaitu dengan menugaskan petugas Panitia Pemungutan Suara (PPS) atau staf Komisi Pemilihan Umum Daerah (KPUD) atau staf Panitia Pemilihan Kecamatan (PPK) untuk diperbantukan di Tempat Pemungutan Suara (TPS).

\section{Analisis Kesehatan Petugas Kelompok Kerja Pemungutan Suara (KPPS)}

Ke depan, diperlukan penyediaan fasilitas kesehatan dan tim medis untuk petugas Kelompok Penyelenggara Pemungutan Suara, yakni dengan mendirikan posko kesehatan minimal satu di setiap desa/ kelurahan/Panitia Pemungutan Suara (PPS), yang tugasnya khusus untuk melayani keluhan kesehatan dari petugas Kelompok Penyelenggara Pemungutan Suara (KPPS). Sehingga bila ditemukan keluhan yang cukup serius pada petugas Kelompok Penyelenggara Pemungutan Suara (KPPS), petugas kesehatan dapat langsung merujuk ke rumah sakit disekitar agar memperoleh perawatan dokter. Dengan begitu, petugas Kelompok Penyelenggara Pemungutan Suara (KPPS) dapat terhindar dari masalah kesehatan serius yang dapat mengancam jiwanya. Dengan tugas yang tergolong berat ditingkat Tempat Pemugutan Suara (TPS), maka Petugas Kelompok Penyelenggara Pemungutan Suara (KPPS) dinilai berhak memperoleh dukungan fasilitas kesehatan tersebut.

Kemudian, terkait waktu perhitungan dan rekapilasi suara di TPS sebagaimana putusan Mahkamah Konstitusi (MK) tentang uji materi terhadap Pasal 383 ayat (2) Undang-undang Nomor 7 tahun 2017, dengan nomor perkara 20/PUU-XVII/2019 yang intinya Mahkamah Konstitusi (MK) memberikan tambahan waktu selama 12 jam tanpa henti bagi Kelompok Penyelenggara Pemungutan Suara (KPPS) 
untuk menyelesaikan proses penghitungan suara, masih perlu dikaji kembali karena waktu kerja yang cukup panjang dan tanpa jeda tersebut dapat berakibat tidak baik untuk kesehatan.

Menurut dr. Sudjoko Kuswadji, MSc (OM), PKK, SpOk, waktu ideal tubuh manusia bekerja dalam sehari yaitu 8 jam sehari, dalam kondisi tertentu paling lama hingga hingga 12 jam sehari. Kemudian penting dilakukan pemeriksaan kesehatan sebelum seseorang bekerja. (detikhealth, 17 Desember 2013)

Penerapan waktu kerja selama 8 jam sehari juga sejalan dengan peraturan mengenai ketenagakerjaan dalam Pasal 77 ayat 1, UU No.13/2003 yang mengharuskan setiap pengusaha untuk menerapkan aturan waktu kerja selama 8 jam perhari.

Dengan demikian waktu yang disediakan bagi Kelompok Penyelenggara Pemungutan Suara (KPPS) dalam melakukan tugasnya tergolong tidak sehat dari sisi medis. Untuk mengantisipasi jatuhnya korban meninggal dunia pada Pemilu yang akan datang maka aspek kesehatan penyelenggara pemilu juga layak dan patut untuk diperhatikan.

Seyogianya waktu penghitungan suara di TPS dapat diperpanjang paling lama 3 hari dengan waktu yang terputus atau dengan jeda untuk istirahat. Penghitungan suara dilakukan hanya sampai jam 24.00 waktu setempat dan jika belum selesai dilanjutkan keesokan harinya pada jam 08.00 waktu setempat. Sehingga dengan adanya jeda waktu tersebut, penyelenggara pemilu dapat menggunakannya untuk beristirahat dan memulihkan kesegaran dan kesehatan fisik dan mental.

Sedangkan untuk keamanan dan pengamanan dari surat suara dan alat kelengkapan Tempat Pemungutan Suara (TPS) lainnya dapat disimpan di gudang yang telah disepakati misalnya di Kantor Desa/Panitia Pemungutan Suara (PPS). Selanjutnnya gudang penyimpanan surat suara dan perlengakapan Tempat Pemungutan Suara (TPS) dikunci dan segel bersama-sama Kelompok Penyelenggara Pemungutan Suara (KPPS), saksi-saksi, Kepolisian, Tentara Nasional Indonesia (TNI), Pengawas Pemilu Lapangan (PPL) dan dijaga oleh petugas kepolisian sampai dengan dilanjutkannya penghitungan suara keesokan harinya.

Selain itu, Panitia Pemungutan Suara (PPS) ke depan harus lebih cermat lagi dalam melakukan rekrutmen petugas Kelompok Penyelenggara Pemungutan Suara (KPPS). Kesehatan jasmani dan rohani calon petugas Kelompok Penyelenggara Pemungutan Suara (KPPS) menjadi pertimbangan penting, mengingat tugas berat yang harus diemban petugas Kelompok Penyelenggara Pemungutan Suara (KPPS).

Berdasarkan Pasal 72 Undang Undang Nomor 7 tahun 2017 persyaratan untuk menjadi petugas Kelompok Penyelenggara Pemungutan Suara (KPPS), ditentukan diantaranya adalah: a) berusia paling rendah 17 tahun dan b) mampu secara jasmani dan rohani dan bebas dari penyalahgunaan narkotika;

Dari persyaratan tersebut, Panitia Pemungutan Suara (PPS) dalam melakukan perekrutan petugas Kelompok Penyelenggara Pemungutan Suara (KPPS) harus mempertimbangkan dari segi umur calon Kelompok Penyelenggara Pemungutan Suara (KPPS). Calon Kelompok Penyelenggara Pemungutan Suara (KPPS) yang tergolong lansia haruslah betul-betul dipertimbangkan kesehatannya, untuk mengantisipasi kemungkinan terjadinya gangguan kesehatan saat bertugas.

Mengingat persyaratan minimal umur calon petugas Kelompok Penyelenggara Pemungutan Suara (KPPS) berusia paling rendah 17 tahun, maka PPS dapat memprioritaskan pemuda dan pemudi untuk diangkat menjadi petugas Kelompok Penyelenggara Pemungutan Suara (KPPS). Pada umumnya petugas 
Kelompok Penyelenggara Pemungutan Suara (KPPS) selama ini hanya didominasi oleh orang-orang tua saja.

Kemudian persyaratan terkait mampu secara jasmani dan rohani serta bebas dari penyalahgunaan narkoba haruslah dikeluarkan oleh Rumah Sakit yang terakreditasi, bukan dari puskesmas atau praktek dokter/klinik, karena rumah sakit yang terakreditasi memiliki fasilitas yang memadai untuk pemeriksaan kesehatan.

Selama ini persyaratan kesehatan masih dianggap sebatas formalitas saja dan persyaratan kesehatan yang diserahkan kepada panitia pendaftaran belum mencerminkan keadaan kesehatan calon Kelompok Penyelenggara Pemungutan Suara (KPPS) yang sesungguhnya, padahal ini sangat penting untuk menjamin kesiapan dan keselamatan petugas Kelompok Penyelenggara Pemungutan Suara (KPPS) dalam bekerja.

Walaupun petugas Kelompok Penyelenggara Pemungutan Suara (KPPS) masa tugasnya singkat (ad hoc) yaitu sebulan saja, namun rekrutmen petugas Kelompok Penyelenggara Pemungutan Suara (KPPS) harus dilakukan dengan serius. Tidaklah tepat anggapan bahwa Kelompok Penyelenggara Pemungutan Suara (KPPS) adalah lembaga ad hoc yang peranannya kurang penting dan hanya memiliki kontribusi kecil dalam kesuksesan penyelenggaraan pemilu. Kesuksesan penyelenggaraan pemilu di Indoneisa terletak pada "pundak" seluruh jajaran penyelenggara pemilu, dari mulai KPU hingga Kelompok Penyelenggara Pemungutan Suara (KPPS), tanpa terkecuali. Seluruh jajaran penyelenggara pemilu baik permanen maupun ad hoc sama-sama berperan penting dan memiliki kepentingan yang sama untuk mensukseskan Pemilu. Seluruh penyelenggara pemilu dibebankan tugas, tanggung jawab dan kewenangan sesuai dengan tingkatannya masing-masing.
Sehingga seluruh jajaran KPU dapat bersama-sama melaksanakan tugasnya sesuai dengan prinsip-prinsip penyelenggara pemilu berdasarkan Pasal 3 UU No 7 Tahun 2017 yaitu a) mandiri, b) jujur, c) adil, d) berkepastian hukum, e) tertib, f) terbuka, g) proporsional, h) profesional, i) akuntabel, j) efektif, k) efisien.

Selain itu, bila mengacu pada standar International Institute for Democrcy and Electoral Assistence, prinsip utama Penyelenggara Pemilu dalam menyelenggarakan pemilu yaitu (Surbakti dan Nugroho, 2015): a) independen; b) imparsialitas; c) integritas; d) transparansi; e) efisiensi; f) profesionalisme; g) mengutamakan pada pelayanan (service-mindedness).

Sehingga, dengan menjalankan tugas dan kewajiban sesuai prinsip-prinsip tersebut diatas, maka KPU beserta seluruh jajarannya akan mendapatkan kepercayaan dari publik.

\section{SIMPULAN}

Pengelolaan tugas, kewajiban dan kewenangan petugas Kelompok Penyelenggara Pemungutan Suara sebagaimana yang tercatum dalam Undang-Undang Nomor 7 tahun 2017 tentang Pemilihan Umum kedepan perlu disempurkan untuk dapat mengatur secara rinci pembagian tugas dan kewajiban Kelompok Penyelenggara Pemungutan Suara pada tahap penghitungan suara. Sehingga tugas dan kewajiban dapat dilaksanakan secara proporsional dan merata. Kemudian petugas Kelompok Penyelenggara Pemungutan Suara perlu diberikan bimbingan teknis yang memadai terkait tugas, kewajiban, tata cara pemungutan dan penghitungan suara serta pemecahan masalah sehingga petugas memiliki kesiapan dan kesigapan dalam pelaksanaan tugas dan kewajibannya.

Aspek kesehatan petugas KPPS kedepan harus lebih diperhatikan yaitu dengan mempertimbangkan jam kerja bagi 
petugas KPPS yakni tidak melebihi dari delapan jam sehari. Kemudian pelaksanaan rekrutmen petugas KPPS kedepan harus dilakukan dengan cermat dalam hal penelitian persyaratan administrasi kesehatan. Dimana surat keterangan kesehatan calon petugas KPPS haruslah dikeluarkan oleh Rumah Sakit yang terakreditasi. Hal tersebut dapat menjamin kualitas kesehatan calon petugas KPPS.

\section{DAFTAR PUSTAKA}

Farisa, F.C. (2019). KPU Bakal Evaluasi Sistem Pelaksanaan Pemilu Serentak 2019. Diunduh dihttps://nasional.kompas.com/read/2019/ 04/23/05212831/kpu-bakal-evaluasisistem-pelaksanaan-pemilu-serentak-2019. tanggal 12 Mei 2019

Nursalikash, A. (2019). Pengawas Pemilu Di Jember Keguguran Karena Kelelahan. Diunduh dihttps://nasional.republika.co.id/berita/na sional/daerah/pqeofg366/pengawaspemilu-di-jember-keguguran-karenakelelahan. Tanggal 12 Mei 2019

Putri, Z. (2019). Bertambah Lagi, Petugas KPPS yang Meninggal Jadi 469 Orang. Diunduh di https://news.detik.com/berita/d4544623/b ertambah-lagi-petugas-kpps-yangmeninggal-jadi-469-orang. tanggal 12 Mei 2019

Rahmatunnisa, M. (2017). Mengapa Integritas Pemilu Penting?. Jurnal Bawaslu. 3 (1) : 1-11

Republik Indonesia. (2013). Undang-Undang No. 13 Tahun 2003 Tentang Ketenagakerjaan. Lembaran Negara RI Tahun 2017, No. 39. Sekretariat Negara. Jakarta.

Republik Indonesia. (2017) . Undang-Undang No. 7 Tahun 2017 Tentang Pemilihan Umum.
Lembaran Negara RI Tahun 2017, No. 182. Sekretariat Negara. Jakarta.

Republik Indonesia. (2019). Peraturan Komisi Pemilihan Umum No. 3 Tahun 2019 Tentang Pemungutan dan Penghitungan Suara Dalam Pemilihan Umum. Jakarta

Riskiyono, J. (2013). Hak Publik Berpartisipasi Mewujudkan Penyelenggaraan Pemilu Demokratis. Jurnal Pemilu dan Demokrasi. $6: 115-144$

Sanjaya, F. (2012). Peran Moderasi Kecerdasan Emosi Pada Stres Kerja. Jurnal Dinamika Manajemen. 3 (2) : 155-163

Sarwono, J. (2006). Metode Penelitian Kuantitatif dan Kualitatif. Yogyakarta: Graha Ilmu

Soliha, R. (2018). Peluang dan Tantangan Pemilu Serentak 2019 Dalam Perspektif Politik. Jurnal Ilmiah Ilmu Pemerintahan. 3 (1): 7388

Surbakti, R. \& Nugroho K. (2015). Studi tentang Desain Kelembagaan KPU yang Efektif. Kemitraan.Jakarta. Bagi Pembauran Tata Pemerintahan

Tallo, J. (2019). Penghitungan Suara Pemilu 2019 di TPS Dimulai Pukul 13.00 Waktu Setempat. Diunduhdihttps://www.liputan6.com/pileg/ read/3943206/penghitungan-suara-pemilu2019-di-tps-dimulai-pukul-1300-waktusetempat. tanggal 12 Mei 2019

Triono. (2017). Menakar Efektivitas Pemilu Serentak 2019. Jurnal Wacana Politik. 2 (2) : 156-164

Vit. (2013). Berapa Jam Idealnya Tubuh Manusia Bekerja dalam Sehari?. Diunduh di https://health.detik.com/berita.detikhealth/ d-2444247/berapa-jam-idealnya-tubuhmanusia-bekerja-dalam-sehari. tanggal 12 Mei 2019

Wijaya, C. \& Rifai. (2016). Dasar-Dasar Manajemen Mengoptimalkan Pengelolaan Organisasi Secara Efektif dan Efisien. Medan. Perdana Publishing 